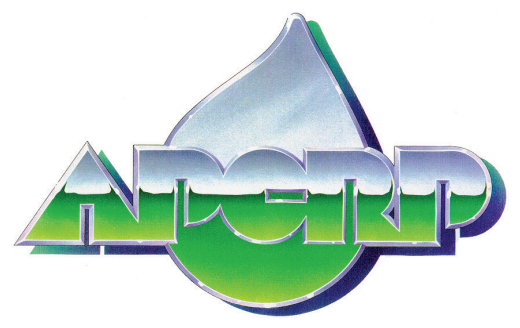

ERDC/TN APCRP-BC-38

June 2016

\title{
Surveys for Pathogens of Monoecious Hydrilla 2014
}

by Judy F. Shearer

PURPOSE: This technical note describes the results of 2014 surveys in the Eastern United States for pathogenic agents on monoecious hydrilla.

INTRODUCTION: Monoecious hydrilla is increasingly becoming a problem in the United States. It was first discovered in Delaware in 1976 and later in the Potomac River (Haller 1982, Steward et al. 1984). Shortly after its discovery in 1982, Steward et al. (1984) predicted that monoecious hydrilla could potentially invade all of the lower 48 states as well as southern and central Canada. As of 2011, it had been reported from 23 states: Delaware, California, Connecticut, Maryland, North Carolina, Virginia, Pennsylvania, Washington, Indiana, Iowa, Kentucky, Massachusetts, Maine, Wisconsin, New Jersey, West Virginia, New York, Ohio, Missouri, South Carolina, Tennessee, Georgia, and Alabama ${ }^{1}$. Although the infestation in Iowa was never positively identified as monoecious, it is highly likely it was because the pistillate dioecious biotype is much more common in the Southeast than the Midwest. The Washington State population no longer exists due to an aggressive eradication program ${ }^{2}$. It is believed that populations in Iowa and Wisconsin have also been eradicated ${ }^{1}$. The most recent invasions have appeared in Lake Cayuga, the Erie Canal at North Tonawanda, upstate New York (Lansing Star 2012), and in the Croton River near New York City (DEC 2015).

The biology and growth form of dioecious and monoecious hydrilla biotypes are very different. Compared to the monoecious biotype, dioecious plants tend to have growth that is more vigorous. Dioecious plants grow vertically to the water surface, then spread laterally forming a mat (Van 1989). Madeira et al. (1997) hypothesized that this growth form was an adaptation to deep water generated from monsoons on the Indian subcontinent. The subterranean turions (i.e., tubers) of the dioecious biotype are larger than those of the monoecious biotype and are formed under short-day conditions (Van 1989). In contrast, the tubers of the monoecious biotype are produced under longday photoperiods and are smaller. When they germinate, the stems tend to grow laterally, generating new root crowns along the sediment surface that result in high shoot densities (Van 1989). When the monoecious hydrilla mat declines in the fall, it breaks loose and fragments containing numerous axillary propagules (i.e., turions) drift in the water currents dispersing the plant (Steward and Van 1987). Madeira et al. (1997) hypothesized that the growth and reproductive habits were adaptations to northern climates, which suggests a temperate origin of the plant that was consistent with its' probable Korean origin.

\footnotetext{
${ }^{1}$ Netherland, M. 2013. Research Biologist. Engineer Research and Development Center, Gainesville, FL.

2 Parsons, J. 2012. Aquatic Plant Specialist. State of Washington Department of Ecology, Olympia, WA.
} 
While dioecious hydrilla has been surveyed for pathogenic agents periodically over the past 25 years (Joye and Cofrancesco 1991, Shabana and Charudattan 1996, Shabana et al. 2003, Shearer 2012), monoecious hydrilla has received less attention. In part, this was due to its limited distribution in a few eastern states, but its expansion in recent years to widely different geographic regions of the United States has given it new status as an invasive species of great concern.

Monoecious hydrilla management is primarily through chemical control using endothall (Poovey and Getsinger 2010), fluridone, and a combination of copper and diquat ${ }^{1}$. Grass carp (Ctenopharyngodon idella), are currently stocked in some sites having monoecious hydrilla, specifically Lake Gaston along the Virginia/North Carolina border and at Lake Guntersville in Alabama. A technical note by Dick et al. (in review) indicates that there is little evidence that grass carp have contributed to hydrilla control at Lake Gaston. The authors attribute the lack of control to stocking rates that are not high enough to manage hydrilla successfully. Moreover, high stocking rates can result in removal of non-target species, an outcome that might be highly undesirable in native aquatic plant restoration efforts. While the ephydrid fly (Hydrellia pakistanae), a biocontrol insect, has successfully established populations on the dioecious hydrilla biotype, there are no records that document establishment on the monoecious hydrilla biotype, even after concerted release efforts. The fly overwinters as larvae and pupae in dioecious hydrilla stem tissue in Texas (Harms and Grodowitz 2011). Establishment would be much more problematic on monoecious hydrilla because the plant acts like an annual; i.e., stem plant tissue dies back in the late fall/early winter, and overwintering occurs by tubers and turions. There is also some speculation that the less robust spreading growth form of the plant, compared to dioecious hydrilla that forms a surface mat, might be a detriment to fly establishment (Grodowitz et al. 2010).

Several pathogens have been researched as potential biological control agents for management of dioecious hydrilla including Mycoleptodiscus terrestris (Joye and Cofrancesco 1991, Joye 1990, Joye and Paul 1991, Nelson et al. 1998, Netherland and Shearer 1996, Shearer 1998, Shearer 2009a, 2009b, Shearer and Nelson 2002, Shearer and Jackson 2006), Fusarium culmorum (Charudattan et al. 1984), and Plectosporium tabacinum (Smither-Kopperl et al. 1999). Mycoleptodiscus terrestris is efficacious on monoecious hydrilla (Shearer, personal observation). Research conducted in 2011 (Shearer 2012) found two additional Myrothecium pathogens to also be efficacious on monoecious hydrilla. The purpose of the study presented herein was to survey some known populations of monoecious hydrilla and isolate additional fungal pathogenic strains of Myrothecium and/or other potential pathogenic biocontrol agents.

MATERIALS AND METHODS: During the summer 2014, collections of monoecious hydrilla were made in Georgia/South Carolina (Strom Thurmond Reservoir), Texas (Lewisville Aquatic Ecosystem Research Facility), Alabama (Lake Guntersville), Virginia (Potomac River), New York (Lake Cayuga and Erie Canal at North Tonawanda), and from culture tanks in Florida (University of Florida, Gainesville). Samples were shipped overnight to the U.S. Army Corps of Engineers Research and Development Center (ERDC), Vicksburg, Mississippi. Upon arrival, the samples were washed in running water to remove any soil or debris attached to stems and leaves. The samples were wrapped in moist paper toweling, placed in plastic bags and kept at $4^{\circ} \mathrm{C}$ until they could be processed.

\footnotetext{
${ }^{1}$ Netherland, M. 2013. Research Biologist. Engineer Research and Development Center, Gainesville, FL.
} 
The samples were processed by dilution plating. A $10 \mathrm{~g}$ subsample of stem and leaf tissue from each collection was surface sterilized in a 3.5\% sodium hypochlorite solution for $1 \mathrm{~min}$, placed in a sieve, and rinsed in deionized water for $1 \mathrm{~min}$. Excess moisture was drained off the subsample, and it was added to a blender containing $100 \mathrm{ml}$ of sterile water. The subsample was macerated in the blender for $30 \mathrm{~s}$, providing a dilution factor of $1 / 10$. The resulting slurry was further diluted to concentrations of 1/50 and 1/100. All dilutions were plated onto Martin's agar (MA) (Martin 1950) plates (3 plates per dilution concentration). The plates were incubated in the dark at $25^{\circ} \mathrm{C}$ for 1 week. Small pieces $(\sim 1 \mathrm{~mm}$ by $1 \mathrm{~mm})$ were cut from the leading edge of filamentous fungal colonies on the plates and transferred to Potato Dextrose Agar (PDA; Difco Inc., Detroit, MI) slants (test tubes placed at an angle during cooling to give a large slanted surface for inoculation). After 7-10 days, the slants from each of the geographic regions were sorted and enumerated into morphospecies based on gross colony morphology and color. The cultures were stored at $4^{\circ} \mathrm{C}$ until they could be plated for identification. Each morphological "species" was plated onto Potato Carrot Agar (PCA) (Dinghra and Sinclair 1995) and PDA and incubated at $25^{\circ} \mathrm{C}$ under a grow light (Plant and Aquarium, General Electric Company, Cleveland, $\mathrm{OH}$ ) for 1 to 3 weeks to induce sporulation. Both agars are important for isolate identification because characteristic colors and growth patterns develop on PDA, and colonies readily produce asexual and/or sexual spores on PCA. Those cultures that sporulated were identified to genus and species when possible. Those that did not sporulate were placed in categories of moniliaceous (hyaline hyphae) or dematiaceous (dark hyphae) Ascomycetes. There could have been several different species, but they were not compared morphologically or by colony color to try to further separate them across sites.

RESULTS AND DISCUSSION: There were 22 monoecious hydrilla samples processed from different geographical regions of the United States in 2014: Georgia/South Carolina (3), Texas (2), Alabama (2), Virginia (4), New York (7), and Florida (4). When the MA plates were examined for colony growth, only one of each colony type was selected; however, all similar colonies were counted, thus the high numbers of some isolates (Table 1). For example, there were 196 colonies of Fusarium redolens that grew from the two plant samples collected at Lake Guntersville in Alabama. One hundred ninety-two morphospecies were obtained from the seven geographic locations; following identification, they were reduced to 85 morphospecies because the more common species occurred in several different sites (Table 1). Genera, where potential species were lumped together across collections, included Phoma, Penicillium, and Acremonium. The main reason they were not identified to species was based upon experience, as the time required for identification could not be justified for a set of saprophytic species that in all likelihood would not have been pathogenic on hydrilla. Sixty-one or $72 \%$ of the morphospecies were singletons occurring at only one site. This was a slight increase in what was found in surveys conducted in 2012 (61\% versus $72 \%)$. When combining the singletons and the doubletons (those species occurring at two sites), these account for $82 \%$ of the total, which was very similar to species recovered in 2012 ( $81 \%$ versus $82 \%$ ) (Shearer 2014). It would appear that except for a few ubiquitous species, in general, each site has a unique set of mycoflora associated with hydrilla.

The majority of the species isolated during the study could be described as cosmopolitan saprobes, or secondary weak pathogens and, as such, would not make good candidates for biological control of monoecious hydrilla. It is also interesting to note how many species (e.g., Acremonium strictum, Alternaria alternata, Fusarium oxysporum, Myrothecium verrucaria, Trichoderma aureoviride, and Colletotrichum gloeosporioides to name a few) were indeed cosmopolitan and were also found 
during a survey for water borne organisms in India (Parveen 2013). Eighty species were found in a stream in India compared to 85 in the monoecious hydrilla survey conducted in the United States. Of these, there were 15 species and six genera in common between the two surveys.

\begin{tabular}{l}
\hline Table 1. Eighty-five fungal species were isolated from monoecious hydrilla collected at Cayuga \\
Lake (CL), Lewisville (L), Lake Guntersville (LG), Strom Thurmond Reservoir (ST), Erie Canal (EC), \\
Potomac River (PR), and from culture tanks T65 (Erie Canal), T57 (Lake Gaston), T72 (Lake \\
Gaston), and T23 (Strom Thurmond Reservoir) located in Gainesville FL. Those species with an \\
asterisk following the name are potential pathogens.
\end{tabular}

\begin{tabular}{|c|c|c|c|c|c|c|c|c|c|c|}
\hline \multirow[b]{2}{*}{ Species } & \multicolumn{6}{|c|}{ Collections from field sites } & \multicolumn{4}{|c|}{$\begin{array}{c}\text { Collections from culture } \\
\text { tanks }\end{array}$} \\
\hline & $\overline{C L}$ & $\bar{L} \mathbf{L}$ & LG & ST & EC & PR & T65 & T57 & T72 & T23 \\
\hline Trichoderma harzianum* & 1 & 1 & 1 & 4 & 4 & 1 & 1 & & & \\
\hline Plectosphaerella cucumerina* & 20 & & & 4 & & & & & & \\
\hline Nodulisporium sp.* & 7 & & & 4 & & & & & & \\
\hline Phialophora spp. hoffmanii gp & 22 & & & 1 & & & & & & \\
\hline Cladosporium tenuissimum & 10 & & & & & & & & & \\
\hline Sporobolomyces sp. ${ }^{*}$ & 1 & & & & & & & & & \\
\hline Dematiaceous Ascomycete* & 3 & 1 & 18 & 1 & 1 & 34 & 1 & 2 & 3 & \\
\hline Moniliaceous Ascomycete* & 5 & & 1 & 10 & 2 & 15 & 14 & & & \\
\hline Cladosporium cladosporioides & 6 & & & & & & & & & \\
\hline Pestalotiopsis guepinii $^{*}$ & 9 & & & & & 1 & 1 & & & 14 \\
\hline Mucor sp.* & 5 & & & & & & & & & \\
\hline Myrothecium verrucaria* & 7 & & & & & & & & & \\
\hline Hansfordia ovalispora* & 3 & & & 2 & & 1 & & & & 1 \\
\hline Microsphaeropsis olivacea* & 5 & 1 & 3 & & 1 & 8 & & & & \\
\hline Alternaria alternata & 2 & & & & 4 & 2 & & & & \\
\hline Phialophora sp. & 2 & & 1 & & & 2 & & & & \\
\hline Nodulisporium ochraceum* & 1 & 1 & & & 2 & & & & & \\
\hline Phoma spp.* & 1 & 1 & 1 & 1 & 81 & 5 & 28 & 207 & 1 & 1 \\
\hline Oidiodendron sp. & & 1 & & & & & & & & \\
\hline Cladosporium sphaerospermum & & 1 & & 3 & 5 & 1 & & & & \\
\hline Hansfordia biophila* & & 2 & & & & & & & & \\
\hline Fusarium redolens* & & & 196 & & & & & & & \\
\hline Graphium sp. & & & 5 & & & & & & & \\
\hline Acremonium curvulum* & & & 3 & & & & & & & \\
\hline Acremonium charticola* & & & 9 & 2 & 4 & 2 & & & & \\
\hline Paecilomyces carneus* & & & 1 & & & & & & & \\
\hline Fusarium lateritium $^{*}$ & & & 9 & & & & & & & \\
\hline Trichoderma hamatum & & & 7 & & & & & & & \\
\hline Mortierella sp. & & & 1 & & & & & & & \\
\hline Curvularia lunata & & & & 2 & & & & & & \\
\hline Penicillium spp. & & & & 5 & & 1 & & 3 & & \\
\hline Cladosporium oxysporum & & & & 1 & & & & & & \\
\hline Pseudeurotium ovalis & & & & 1 & & & & & & \\
\hline Isaria sp. & & & & 1 & & & & & & 1 \\
\hline Helicoma state of Lasiosphaeria pisicola & & & & 1 & & & & & & \\
\hline Drechslera dematoidea* & & & & 1 & & & & & 1 & \\
\hline
\end{tabular}




\begin{tabular}{|c|c|c|c|c|c|c|c|}
\hline Cladosporium cucumerinum & 1 & & & & & & \\
\hline Talaromyces stipitatus & 1 & & & & & & \\
\hline Ditangium sp. & 1 & & & & & & \\
\hline Gliomastix murorum & 1 & & & & & & \\
\hline Trichoderma piluliferum & 1 & & & & & & 1 \\
\hline Emericellopsis minima* & 3 & & & & & & \\
\hline Aspergillus ochraceus & 2 & & & & & & \\
\hline Acremonium potronii & 4 & & & & & & \\
\hline Acremonium terricola & 2 & & & 1 & & & \\
\hline Geotrichum sp. & 1 & 1 & 1 & & & & \\
\hline Aspergillus flavus & & 2 & & & & & \\
\hline Cladosporium inaequalis & & 2 & & & & & \\
\hline Harpographium fasciculatum* & & 1 & & & & & \\
\hline Trichoderma aureoviride & & 1 & 1 & & & & \\
\hline Acremonium strictum* & & 1 & & & & & \\
\hline Phoma levelei* & & 3 & & & & & \\
\hline Macrophoma sp. ${ }^{*}$ & & 2 & & 3 & 1 & & \\
\hline Apiospora montagnei* & & 1 & & & & & \\
\hline Botryoderma sp.* & & 1 & & & & & \\
\hline Cladosporium nigellum & & 1 & & & & & \\
\hline Acremonium ochraceum* & & 1 & & & & & \\
\hline Fusarium oxysporum* & & 1 & & 1 & & & \\
\hline Paecilomyces lilacinus & & 2 & & & & & \\
\hline Acremonium bacillosporus & & 3 & & & & & \\
\hline Acremonium sp. ${ }^{*}$ & & & 573 & 2 & & & \\
\hline Pythium sp. & & & 15 & & & & \\
\hline Penicillium oxalicum & & & 1 & & & & \\
\hline Arthrinium phaeospermum & & & 2 & & & & \\
\hline Hyaline aleuriospores & & & 53 & & & & \\
\hline Acremonium furcatum & & & 1 & & & & \\
\hline Colletotrichum gloeosporioides* & & & 4 & & & & \\
\hline Pleospora sp. & & & 1 & & & & \\
\hline Aureobasidium pullulans & & & 1 & & & & \\
\hline Candida sp. & & & 3 & & & & \\
\hline Acremonium humicola* & & & 1 & & & & \\
\hline Gliocladium viride & & & 1 & & & & \\
\hline Chaetomium dolichotrichum & & & 1 & & & & \\
\hline Sporormiella subtilis & & & 1 & & & & \\
\hline Myrothecium roridum* & & & & 5 & & & \\
\hline Staphlotrichum coccosporium* ${ }^{*}$ & & & & 1 & & & \\
\hline Fusarium sp. & & & & 1 & & & \\
\hline Ophiosphaerella herpotrichia* & & & & 37 & & & 1 \\
\hline Verticicladium sp.* & & & & & 1 & & \\
\hline Sphaeropsis sapinea* & & & & & 1 & & \\
\hline Umbellopsis sp. & & & & & & 5 & \\
\hline Penicillium multicolor & & & & & & 1 & \\
\hline Periconia atra & & & & & & & 1 \\
\hline Pithomyces atro-olivaceus & & & & & & & 2 \\
\hline
\end{tabular}


Seven potential pathogens of monoecious hydrilla found during the 2014 survey included A. curvulum, M.roridum, Plectosphaerella cucumerina, Fusarium spp., H. ovalispora, C. gloeosporioides, and Phoma spp.

Acremonium curvulum: Andrews et al. (1981) identified A. curvulum as a potential biocontrol pathogen of Myriophyllum spicatum L. (Eurasian watermilfoil). At times, the fungus also occurred benignly in some watermilfoil populations as an endophyte. The researchers found that when $A$. curvulum was inoculated onto watermilfoil plants that were endophyte-free, it was only mildly pathogenic; but when it was inoculated onto plants that were endophyte-infected, the stressed plants usually died. These findings resulted in curtailment of further development of the agent due to inconsistent efficacy in the laboratory. It is unknown at the present time if pathogen performance would be similar on monoecious hydrilla.

Myrothecium roridum: Two Myrothecium species have been evaluated as biological control agents. Myrothecium roridum has been suggested as a possible mycoherbicidal agent for control of Eichhornia crassipes (Mart.) Solms. (waterhyacinth) (Okunowo et al. 2008) and H. verticillata and M. spicatum (Shearer, unpublished data). Okunowo et al. (2010b) focused on optimum growth parameters of the fungus, but efficacy testing on waterhyacinth was not included. Because species of Myrothecium can produce cellulolytic enzymes, M. roridum might have potential as a pathogenic agent both for waterhyacinth (Moreira et al. 2005, Okunowo et al. 2010a) and monoecious hydrilla. Myrothecium verrucaria has shown excellent potential as a biological control agent against several species of plants including Sesbania exaltata (Mill.) McVaugh (hemp sesbania) (Boyette et al. 2014), Pueraria montana (Lour.) Merr. (kudzu) (Abbas et al. 2001, Boyette et al. 2002, Hoagland et al. 2012, Hoagland et al. 2007), and Ipomoea spp. (morning glory) (Hoagland et al. 2011),

Plectosphaerella cucumerina: In the late 1990s, Smither-Kopperl et al. (1999) isolated Plectosporium tabacinum (anamorph Plectosphaerella cucumerina) from asymptomatic dioecious hydrilla. In an aquarium study, the fungus could spread to other plants from a single infected shoot. However, it was considered weakly pathogenic and the authors recommended it be used with herbicides in an integrated approach for hydrilla management. This approach might also be applied when using $P$. cucumerina as a biocontrol fungus for monoecious hydrilla management.

Fusarium spp.: The genus Fusarium is represented with many necrotrophic plant pathogenic fungi causing disease on different plant species worldwide (Agrios 2005). During the 2014 surveys, at least four different species were isolated from monoecious hydrilla: Fusarium. oxysporum, F. redolens (sometimes referred to as $F$. oxysporum f. sp. redolens), F. lateritium and an unidentified Fusarium sp. The F. oxysporum complex consists of different forma specialis depending on the host they infect (Agrios 2005). In natural systems, F. oxysporum, F. redolens, and F. lateritium are all soil borne pathogens. When a host is present, the spores germinate and the mycelium penetrates plant roots and then enters the vascular system where the fungus ramifies, causing wilting symptoms and eventually plant death. According to Farr et al. (1989), few aquatic plants have been subject to infection by a Fusarium species. Fusarium oxysporum has been reported on Alternanthera philoxeroides (alligatorweed) and F. crookweilense has been reported on Potamogeton crispus (curly pondweed) and Potamogeton nodosus (longleaf pondweed). 
Hansfordia ovalispora: Farr et al. (1989) provided no reports of a Hansfordia on any plant species in the United States as of 1980. However, during a survey in the Great Smoky Mountains National Park, H. ovalispora was isolated in 2004 from damaged bark of a Fraser fir tree (Baird et al. 2007). It was also isolated from monoecious hydrilla collected in California and in South Carolina (Shearer 2014). During the present survey, H. ovalispora was isolated from four different collections of monoecious hydrilla (Table 1). It was also isolated from diseased Butomus umbellatus (flowering rush) tissues collected in 2014 in the Pacific Northwest (Harms and Shearer 2015). These results indicate that the species is more widespread than previously thought.

Colletotrichum gloeosporioides: Members of the genus Colletotrichum are pathogenic on a variety of annual and perennial plants, causing an anthracnose disease that is characterized by dark lesions with pink or orangish masses of spores in the center (Agrios 2005). Specifically, C. gloeosporioides has been documented on nearly 200 genera of vascular plants in the United States alone (Farr et al. 1989). One of these genera, forma specialis, C. gloeosporioides f. sp. aeschynomene, was originally registered in 1982 under the trade name Collego as a biological control agent for Aeschynomene virginica (Northern joint vetch), a weed in rice fields (Charudattan 2010). Collego had such a small market that manufacturing was discontinued, but in recent years the bioherbicide has been reintroduced under the tradename Lockdown Retro by Natural Industries Inc., Houston, TX. It would seem unlikely that $C$. gloeosporioides could be developed as an effective biological control agent for monoecious hydrilla because it is a submersed rather than a terrestrial plant. Natural spread of the fungus is by rain splash or by insects, animals, or humans moving among host plants. In the 2014 surveys, the fungus probably was present as a benign endophyte in host tissues, rather than as a pathogen on exposed tissues.

Phoma spp.: The genus Phoma is one of the largest in the Kingdom Fungi, containing an estimated 3,000 taxa (Aveskamp et al. 2010). In general, the genus is comprised of two large groups, one containing plurivorous fungi that are saprobic or weakly parasitic and a second group many of which are pathogenic to a variety of cultivated plants, including members of the Brassicaceae (cabbage family) and the Solanaceae (tomato family) (Agrios 2005). With a few exceptions, no attempt was made to identify the Phoma's isolated from monoecious hydrilla to species because the genus is so large and few good keys are available for the majority of species. Past studies have shown that Phoma spp. that have been isolated from hydrilla are saprobic, or weakly parasitic, and do not make good biocontrol candidates (Shearer 2012, 2014).

FUTURE WORK: The above mentioned potential pathogens (Acremonium curvulum, Plectosphaerella cucumerina, Colletotrichum gloeosporioides, Hansfordia ovalispora, Myrothecium roridum, Fusarium spp., and Phoma spp.) will be screened for pathogenicity on monoecious hydrilla in a small scale flask study. Also included in the testing will be all the unknown dematiaceous and moniliaceous Ascomycetes, and those known as weak pathogens. Those isolates identified as cosmopolitan saprobic species will not be tested e.g., members of the genus Penicillium, Curvularia, Cladosporium, and Trichoderma.

ACKNOWLEDGEMENTS: Support for this project was provided by the Aquatic Plant Control Research Program (APCRP). The author would like to thank, Robert Johnson, Ken Boyd, Nathan Harms, Lynde Dodd, Nancy Rybicki, Linda Nelson, Mike Netherland, and Zack Banks for collecting monoecious hydrilla samples. Thanks also go to Michael Grodowitz and Lynde Dodd for reviewing the manuscript. 
POINTS OF CONTACT: For additional information, contact the author Dr. Judy F. Shearer (601) 634-2516,Judy.F.Shearer@erdc.dren.mil or the Assistant Technical Director, Linda S. Nelson (601) 634-2656,Linda.S.Nelson@usace.army.mil. This technical note should be cited as follows.

Shearer, J. F. 2016. Surveys for pathogens of monoecious hydrilla 2014. APCRP Technical Notes Collection. ERDC/TN APCRP-BC-38. Vicksburg, MS: U.S. Army Engineer Research and Development Center. http://ed.eerdc.usace.army.mil/aqual

\section{REFERENCES}

Abbas, H. K., H. Tak, C. D. Boyette, W. T. Shier, and B. B. Jarvis. 2001. Macrocyclic trichothecenes are undetectable in kudzu (Pueraria montana) planst treated with a high-producing isolate of Myrothecium verrucaria. Phytochemistry 58:269-276.

Agrios G. N. 2005. Plant Pathology $5^{\text {th }}$ ed. Burlington, MA: Elsevier Academic Press.

Aveskamp, M. M., J. de Gruyter, J. H. C. Woudenberg, G. J. M. Verkley, and P. W. Crous. 2010. Highlights of the Didymellaceae: A polyphasic approach to characterise Phoma and related pleosporalean genera. Studies in Mycology 65:1-60.

Andrews, J. H., E. P. Hecht, and S. Bashirian. 1981. Association between the fungus Acremonium curvulum and Eurasian water milfoil, Myriophyllum spicatum. Can. J. Bot. 60:1216-1221.

Baird, R. E., C. E. Watson, and S. Woolfolk. 2007. Microfungi from bark of healthy and damaged American beech, Fraser fir, and Eastern hemlock trees during an all taxa biodiversity inventory in forest of the Great Smoky Moiuntains National Park. Southeastern Naturalist 6:67-82.

Boyette, C. D., R. E. Hoagland, and K. C. Stetina. 2014. Biological control of the weed hemp sesbania (Sesbania exaltata) in rice (Oryza sativa) by the fungus Myrothecium verrucaria. Agronomy 4:74-89.

Boyette, C. D., H. L. Walker, and H. K. Abbas. 2002. Biological control of kudzu (Pueraria lobata) with an isolate of Myrothecium verrucaria. Biocontrol Science and Technology 12:75-82.

Charudattan, R. 2010. Microbial control of weeds. Symposium: Microbial biocontrol of arthropods, weeds and plant pathogens: Risks, benefits and challenges. Shepherdstown, WV: National Conservation Training Center.

Charudattan, R., T. E. Freeman, R. E. Cullen, and F. M. Hofmeister. 1984. Evaluation of Fusarium roseum 'Culmorum' as a biological control agent for Hydrilla verticillata. Technical Report A-84-5. Vicksburg, MS: U.S. Army Engineers Waterways Experiment Station

Dhingra, O. E., and J. F. Sinclair. 1995. Basic plant pathology methods. CRC Press Inc.: Boca Raton, FL.

Dick, G. O., L. L. Dodd, D. H. Smith, and M. Smart. (In Review). Native aquatic plant restoration as a component of sustainable management of hydrilla in Lake Gaston, North Carolina/Virginia. APCRP Technical Notes Collection. ERDC/TN APCRP-EA-xx. Vicksburg MS: U.S. Army Engineer Research and Development Center.

Farr, D. F., G. F. Bills, G. P. Chamuris, and A. Y. Rossman. 1989. Fungi on plants and plant products in the United States. St. Paul, MN: APS Press.

Grodowitz, M., J. Nachtrieb, N. Harms, and J. Freedman. 2010. Suitability of using introduced Hydrellia spp. for management of monoecious Hydrilla verticillata (L.f.) Royle. APCRP Technical Notes Collection. ERDC/TN APCRPBC-17. Vicksburg MS: U.S. Army Engineer Research and Development Center.

Haller, W. T. 1982. Hydrilla goes to Washington. Aquatics 4:6-7. 
Harms, N. E. and M. J. Grodowitz. 2011. Overwintering biology of Hydrellia pakistanae, a biological control agent of hydrilla. J. Aquat. Plant Manage. 49:114-117.

Harms, N. E., and J. F. Shearer. 2015. Apparent herbivory and indigenous pathogens of invasive flowering rush (Butomus umbellatus L.) in the Pacific Northwest. APCRP Technical Notes Collection. ERDC/TN APCRP-BC-35. Vicksburg MS: U.S. Army Engineer Research and Development Center.

Hoagland, R. E., C. D. Boyette, and H. K. Abbas. 2007. Myrothecium verrucaria isolates and formulations as bioherbicides agents for kudzu. Biocontrol Science and Technology 17:721-731.

Hoagland, R. E., T. S. McCallister, C. D. Boyette, M. A. Weaver, and R. V. Beecham. 2011. Effects of Myrothecium verrucaria on morning glory (Ipomoea) species. Allelopathy Journal 27:151-162.

Hoagland, R. E., C. D. Boyette, K. C. Vaughn, N. D. Teaster, and K. Stetina. 2012. Effects of Myrothecium verrucaria on ultrastructural integrity of kudzu (Pueraria montana var. lobata) and phytotoxin implications. American Journal of Plant Sciences 3:1512-1519.

Joye, G. F. 1990. Biocontrol of Hydrilla verticillata with the endemic fungus Macrophomina phaseolina. Plant Dis. 74:1035-1036.

Joye, G. F., and A. F. Cofrancesco. 1991. Studies on the use of fungal plant pathogens for control of Hydrilla verticillata (L. f.) Royle. Technical Report A-91-4. Vicksburg, MS: U.S. Army Engineer Research and Development Center.

Joye, G. F., and R. N. Paul. 1991. Histology of infection of Hydrilla verticillata by Macrophomina phaseolina. Weed Sci. 40:288-295.

Lansing Star. 2012. Hydrilla discovered in Erie Canal. http://www.lansingstar.com/new-page/8881-hydrilla-discovered-inerie-canal. Accessed 11/12/2015.

Madeira, P. T., K. T. Van, K. K. Steward, and R. J. Schnell. 1997. Random amplified polymorphic DNA analysis of the phonetic relationships among world-wide accessions of Hydrilla verticillata. Aquat. Bot. 59:217-236.

Martin J. 1950. Use of acid, rose bengal, and streptomycin in the plate method for estimating soil fungi. Soil Science 69:215232.

Moreira F. G., R. Simone, M. A. F. Costa, C. G. Marques de Souza, and R. M. Peralta. 2005. Production of hydrolytic enzymes by the plant pathogenic fungus Myrothecium verrucaria in submerged cultures. Braz. J. Microbiol. 36:7-11.

Nelson, L. S., J. F. Shearer, and M. D. Netherland. 1998. Mesocosm evaluation of integrated fluridone-fungal pathogen treatment of four submersed plants. J. Aquat. Plant Manage. 36:73-77.

Netherland, M. D., and J. F. Shearer. 1996. Integrated use of fluridone and a fungal pathogen for control of hydrilla. $J$. Aquat. Plant Manage. 33:4-8.

New York Department of Environmental Conservation (DEC). 2015. DEC awards $\$ 50,000$ contract to survey invasive hydrilla in Croton Bay and the Hudson River. http://search.usa.gov/search? affiliate=nysdec \&query=hydrilla Accessed $11 / 10 / 2015$.

Okunowo, W. O. G. O. Gbenle, A. A. Osuntoki, and A. A. Adekunle. 2008. Investigative study of M. roridum toxin on water hyacinth. Phytopathology 98:S115.

Okunowo, W. O., G. O. Gbenle, A. A. Osuntoki, and A. A. Adekunle. 2010a. Production of cellulolytic enzymes by a phytopathogenic Myrothecium roridum and some avirulent fungal isolates from water hyacinth. J. Biotechnol. 9:10741078.

Okunowo, W. O., G. O. Gbenle, A. A. Osuntoki, and A. A. Adekunle. 2010b. Media studies on Myrothecium roridum Tode: A potential biocontrol agent for water hyacinth. Jour. of Yeast and Fungal Research 1: 55-61. 
Parveen, S., S. Gupta, B. Sharma, and K. Sharma. 2013. Survey of fungal diversity in water and its impact on human health. Trends in Life Sciences 2:1-5.

Poovey, A. G., and K. D. Getsinger. 2010. Comparative response of monoecious and dioecious hydrilla to endothall. $J$. Aquat. Plant Manage. 48:15-20.

Shabana, Y. M., and R. Charudattan. 1996. Microorganisms associated with hydrilla in ponds and lakes in North Florida. $J$. Aquat. Plant Manage. 34:60-68.

Shabana, Y. M., J. P. Cuda, and R. Charudattan. 2003. Evaluation of pathogens as potential biocontrol agents of hydrilla. $J$. Phytopathology 151:607-613.

Shearer, J. F. 1998. Biological control of hydrilla using an endemic fungal pathogen. J. Aquat. Plant Manage. 36:54-56.

Shearer, J. F. 2009a. Preliminary testing of Mycoleptodiscus terrestris formulations. APCRP Technical Notes Collection. ERDC/TN APCRP-BC-10. Vicksburg MS: U.S. Army Engineer Research and Development Center.

Shearer, J. F. 2009b. Storage stability of dried microsclerotia of the biological control pathogen Mycoleptodiscus terrestris. APCRP Technical Notes Collection. ERDC/TN APCRP-BC-13. Vicksburg MS: U.S. Army Engineer Research and Development Center.

Shearer, J. F. 2012. Screening of pathogens as potential biological control agents for management of Hydrilla verticillata. APCRP Technical Notes Collection. ERDC/TN APCRP-BC-27. Vicksburg, MS: U. S. Army Engineer Research and Development Center. http://el.erdc.usace.army.mil/elpubs/pdf/tnel12-1.pdf

Shearer, J. F. 2014. Survey for pathogens of monoecious hydrilla. APCRP Technical Notes Collection. ERDC/TN APCRPBC-31. Vicksburg, MS: U. S. Army Engineer Research and Development Center.

Shearer, J. F., and M. A. Jackson. 2006. Liquid culturing of microsclerotia of Mycoleptodiscus terrestris, a potential biological control agent for the management of hydrilla. Biol. Control 38:298-306.

Shearer, J. F., and L. S. Nelson. 2002. Integrated use of endothall and a fungal pathogen for management of the submersed aquatic macrophyte Hydrilla verticillata. Weed Technol. 16:224-230.

Smither-Kopperl, M. L., R. Charudattan, and R. D. Berger. 1999. Plectosporium tabacinum, a pathogen of the invasive aquatic weed Hydrilla verticillata in Florida. Plant Dis. 83:24-28.

Steward, K. K., T. K. Van, V. Carter, and A. H. Pieterse. 1984. Hydrilla invades Washington, D.C. and the Potomac. Amer. J. Bot. 71:162-163.

Steward, K. K., and T. K. Van. 1987. Comparative studies of monoecious and dioecious hydrilla (Hydrilla verticillata) biotypes. Weed Sci. 35:201-210.

Van. T. K. 1989. Differential responses to photoperiods in monoecious and dioecious Hydrilla verticillata. Weed Sci. 37:552-556.

NOTE: The contents of this technical note are not to be used for advertising, publication or promotional purposes. Citation of trade names does not constitute an official endorsement or approval of the use of such products. 